\title{
Comparative study of in vitro antioxidant and anti- inflammatory potentials of two malvaceae used in folk medicine in Burkina Faso
}

\begin{abstract}
The purpose of this study was to evaluate and compare the in vitro antioxidant and antiinflammatory potentials of Wissadula amplissima (L.) and Abutilon grandifolium (Willd.) Sweet, two malvaceae used in the traditional medicine in Burkina Faso. Aqueous, ethanolic and hydroacetonic extracts of these species were used for different assays. Total phenolic and total flavonoid contents were determined using spectrophotometric methods. Antioxidant capacities of the extracts were screened using four methods: DPPH free radical scavenging, ferric reducing antioxidant power (FRAP), total antioxidant capacity (TAOC) and anti-lipid peroxidation assay. The different extracts were also assayed on xanthine oxidase, lipoxygenase and cyclooxygenases 1 and 2 to establish in vitro, their antiinflammatory potentials. Results obtained revealed that the two Malvaceae species were rich in phenolic and flavonoid compounds. These compounds may have antioxidant and anti-inflammatory properties, as in this study we have highlighted the antioxidant capacities and the anti-inflammatory potential of the extracts from the two species. W. amplissima and $A$. grandifolium can be important sources of bioactive molecules with antioxidant and anti-inflammatory properties.
\end{abstract}

Keywords: antioxidant, anti-inflammatory, abutilon grandifolium, wissadula amplissima
Volume 12 Issue $6-2019$

\author{
Emmanuel AM Thiombiano,' Mindiédiba Jean \\ Bangou, ${ }^{1,2}$ Tangbadioa Hervé Coulidiati, ${ }^{1,3}$ \\ Pierre Alexandre Eric Djifaby Sombié, ${ }^{1,4}$ \\ Martin Kiendrébéogo' \\ I Laboratory of Biochemistry and Applied Chemistry (Labioca), \\ University Joseph Ki-Zerbo, Burkina Faso \\ 2Training and Research unit in Sciences and Technology, \\ University Nazi Boni, Burkina Faso \\ 3Training and Research unit in Sciences and Technology, \\ University Norbert Zongo, Burkina Faso \\ 4National Center of Scientific Research and Technology, \\ Institute of Environment and Agricultural Research, Burkina Faso
}

Correspondence: Tangbadioa Hervé Coulidiati,Training and Research unit in Sciences and Technology, University Norbert Zongo, Burkina Faso, Tel (+226)76401633,

Email Coulidiati_her@yahoo.fr

Received: November 06, 2019 | Published: November 18, 2019
Abbreviations: FRAP, ferric reducing antioxidant power; DPPH, $\alpha$-diphenyl- $\beta$-picrylhydrazyl; TAOC, total antioxidant capacity; GAE, gallic acid equivalent; QE, quercetin equivalent; LPI, lipid peroxidation inhibition; AAE, ascorbic acid equivalent; ROS, reactive oxygen species; NOS nitrogen oxygen species; $\mathrm{XO}$, xanthine oxidase; LOX, lipoxygenase; COX 1, cyclooxygenase 1; COX 2, cyclooxygenase 2

\section{Introduction}

Inflammation is a vital immunological process which is indispensable to animal's survival. ${ }^{1}$ Persistent inflammation state can lead to chronic inflammation that can contribute to many common diseases ${ }^{2}$ from infectious to physiological dysfunctioning. ${ }^{3,4}$ Reactive oxygen species (ROS) and nitrogen oxygen species (NOS) are produced during inflammatory processes, and also contribute to amplifying oxidative stress phenomenon. ${ }^{5}$ Oxidative stress and inflammation are two linked pathophysiological processes. ${ }^{6}$ Regulation of reactive species has proven to attenuate the inflammation. ${ }^{7}$ Modern drugs used to treat different forms of inflammatory diseases are known to cause severe side effects, ${ }^{8}$ therefore it is urgent to find a new source of efficient drugs with minimum side effects.

The global use of medicinal plants predates the introduction of antibiotics and other modern drugs. ${ }^{9}$ Plants have an innate ability to biosynthesize a wide range of metabolites capable to attenuate ROS and NOS induced oxidative damage as well as to interact with different physiological mediators and effectors of inflammation in animal's bodies. ${ }^{10}$
Several ethnomedicinal surveys carried out on plants belonging to the Malvaceae family have reported their traditional uses in the treatment of diverse ailments associated with the inflammatory process. ${ }^{11,12}$ In vitro and in vivo investigations also support their efficiency in the modulation of different aspects of inflammation process. ${ }^{13,14}$ The present study was designed to compare the antioxidant potential and inflammatory enzymes inhibition activities of $W$. amplissima and A. grandifolium two species belonging to the Malvaceae family used in the folk medicine of Burkina Faso.

\section{Material and methods}

\section{Collection and authenticity of plant material}

Whole plants of Wissadula amplissima (L.) var. Rostrata (Schumach \& Thonn) R. E. Fries (Malvaceae) and Abutilon grandifolium (Willd.) Sweet (Malvaceae) were harvested in January 2013 in Gampèla $(25 \mathrm{~km}$, East of Ouagadougou, Burkina Faso). Professor Jeanne Millogo-Rasolodimby from the laboratory of Biologie et ecologie végetale (University.of Joseph KI-ZEBO, Burkina Faso) assessed the botanical identity of the plants, then voucher specimens (CI: 16884 and CI: 16885) corresponding respectively to Wissadula amplissima and Abutilon grandifolium were deposited in the university's herbarium. Plant materials collected for different tests were dried at room temperature, pulverized and stored in an airtight bag until use.

\section{Reagents and chemicals}

All chemicals were analytical grade. Sulfuric acid, Dimethyl sulfoxide (DMSO), petroleum ether, acetone, methanol, ethanol, 
Xanthine oxidase from bovine milk (EC 1.17.3.2.), Xanthine, hydrochloric acid $(\mathrm{HCl})$, Lipoxygenase from glycine max (soybean) (EC 1.13.11.12.), linoleic acid, boric acid $\left(\mathrm{H}_{3} \mathrm{BO}_{3}\right)$, gallic acid, quercetin, sodium hydrogenophosphate $\left(\mathrm{Na}_{2} \mathrm{HPO}_{4}, 12 \mathrm{H}_{2} \mathrm{O}\right)$, sodium bicarbonate $\left(\mathrm{NaHCO}_{3}\right)$, L- $\alpha$-lecithin, aluminium trichloride $\left(\mathrm{AlCl}_{3}\right)$, ferric trichloride $\left(\mathrm{FeCl}_{3}\right)$, Folin Ciocalteu reagent (FCR), potassium dihydrogenophosphate $\left(\mathrm{KH}_{2} \mathrm{PO}_{4}\right)$, potassium hexacyanoferrate $\left(\mathrm{K}_{3}\left[\mathrm{Fe}(\mathrm{CN})_{6}\right]\right)$, sodium phosphate $\left(\mathrm{Na}_{3} \mathrm{PO}_{4}\right)$, trichloroacetic acid (TCA), thiobarbituric acid ( TBA), ammonium molybdate $\left(\left(\mathrm{NH}_{4}\right)_{6} \mathrm{Mo}_{7} \mathrm{O}_{24}\right), \alpha, \quad \alpha$-diphenyl- $\beta$-picrylhydrazyl $(\mathrm{DPPH}) \quad$ were purchased from Sigma-Aldrich (St. Louis, MO, USA), COX (ovine/ human) inhibitor screening assay kit was purchased form, Cayman Chemical Compagny, ( New York, NY, USA), Ascorbic acid was supplied from Labosi (Paris, France).

\section{Samples preparation}

Powdered plant material $(50 \mathrm{~g})$ of each species was defatted with petroleum ether $(500 \mathrm{~mL})$ in a Soxhlet extractor before soaked $(48 \mathrm{~h}$, $25^{\circ} \mathrm{C}$, continuous stirring) with $500 \mathrm{~mL}$ of ethanol, mixed acetonewater $(80 / 20 \mathrm{v} / \mathrm{v})$ and water. Hydroacetonic and aqueous extracts were filtrated, concentrated in a vacuum evaporator (Büchi Rotavapor R 200) and lyophilized (Telstar Cryodos 50). The ethanolic extracts after filtration and concentration were left under a hood (Captair Chem, erlab) until the residual organic solvent were evaporated. The different samples were then stored at $4^{\circ} \mathrm{C}$ until use.

\section{Phytochemical quantification}

Determination of total phenolics content: Total polyphenol content in the different extracts was determined according to the method described by Singleton et al. ${ }^{15}$ Briefly, the extracts of $W$. Amplissima and Abutilon grandifolium $(25 \mu \mathrm{L}, 100 \mu \mathrm{g} / \mathrm{mL}$ in methanol) were mixed with Folin Ciocalteu reagent $(105 \mu \mathrm{L}, 0.2 \mathrm{~N})$ and 5 min later sodium bicarbonate $(100 \mu \mathrm{L}, 75 \mathrm{~g} / \mathrm{L})$ was added. After a 1 hour incubation, the absorbance of each mixture was recorded at $760 \mathrm{~nm}$ against a blank with a microplate reader (BioTeck instruments, USA). A standard calibration curve $\left(\mathrm{Y}=0.005 \mathrm{X}+0.00968 ; \mathrm{R}^{2}=0.99\right)$ was plotted using gallic acid $(0-100 \mathrm{mg} / \mathrm{L})$. Polyphenol content was expressed as $\mathrm{mg}$ of gallic acid equivalent per $100 \mathrm{mg}$ of extract (mg GAE/100mg).

Determination of total flavonoids content: The total flavonoids content was estimated according to the method of Dowd as adapted by Arvouet-Grant et al. ${ }^{16}$ Briefly, the extracts of $W$. Amplissima and A. grandifolium $(75 \mu \mathrm{L}, 100 \mu \mathrm{g} / \mathrm{mL})$ were mixed with aluminium trichloride $(75 \mu \mathrm{L}, 2 \%$ in methanol). Absorbances were subsequently read at $415 \mathrm{~nm}$ after $10 \mathrm{~min}$ of incubation against a blank with a UV/ visible spectrophotometer (Epoch, BioTeck instruments, USA). A standard calibration curve $\left(\mathrm{Y}=0.0068 \mathrm{X}+0.0225 ; \mathrm{R}^{2}=0.9945\right)$ was plotted using quercetin $(0-150 \mathrm{mg} / \mathrm{L})$. Total flavonoid content was expressed as $\mathrm{mg}$ of quercetin equivalent per $100 \mathrm{mg}$ of extract (mg QE/100mg)

\section{Antioxidant capacity evaluation}

DPPH radical scavenging assay: DPPH radical scavenging activity was assayed as described by Velázquez et al. ${ }^{17}$ Briefly, $200 \mu \mathrm{L}$ of freshly prepared DPPH solution $(0.02 \mathrm{mg} / \mathrm{mL}$ in methanol) was mixed with $100 \mu \mathrm{L}$ of different extracts of $W$. amplissima and $A$. grandifolium (from 100 to $25 \mu \mathrm{g} / \mathrm{mL}$ in methanol). After shaking, the mixture was incubated for $15 \mathrm{~min}$ in darkness at ambient temperature and absorbance measured at $517 \mathrm{~nm}$ against a blank (methanol) with a microplate reader. Inhibition of DPPH radical was calculated as follows:

$$
\text { DPPH free radical Inhibition } \%: \frac{\mathrm{Abs}_{\text {Blank }}-\mathrm{Abs}_{\text {Sample }}}{\mathrm{Abs}_{\text {Blank }}} \mathrm{X} 100
$$

$\mathrm{Abs}_{\text {Blank }}$ and $\mathrm{Abs}_{\text {Sample }}$ are respectively the absorbances of the blank and the absorbance of the sample. The concentration of extract that scavenges $50 \%$ of DPPH free radicals $\left(\mathrm{IC}_{50}\right)$ was graphically determined. Gallic acid and Quercetin were used as positive controls.

\section{Ferric reducing antioxidant power (FRAP) assay}

The method described by Lamien-Meda et al. ${ }^{18}$ was used to assess the ferric reducing antioxidant power of the different extracts. Briefly, $100 \mu \mathrm{L}(1 \mathrm{mg} / \mathrm{mL}$ in methanol) of each tested sample was mixed with $250 \mu \mathrm{L}$ of phosphate buffer $(0.2 \mathrm{M}, \mathrm{pH} 6.6)$ and $250 \mu \mathrm{L}$ of potassium hexacyanoferrate solution ( $1 \%$ in water). After $30 \mathrm{~min}$ of incubation $\left(50^{\circ} \mathrm{C}\right), 250 \mu \mathrm{L}$ of trichloroacetic acid $(10 \%$ in water) was added and the mixture was centrifuged (2000 $\mathrm{g}$ for $10 \mathrm{~min})$. The supernatant $(125 \mu \mathrm{L})$ was mixed with water $(125 \mu \mathrm{L})$ and $25 \mu \mathrm{L}$ of fresh $\mathrm{FeCl}_{3}$ solution $(0.1 \%$ in water $)$ and then absorbance was read at $700 \mathrm{~nm}$ with a microplate reader. Ferric reduction potential of extracts was expressed in micromole ascorbic acid equivalent per gram $(\mu \mathrm{mol}$ $\mathrm{AAE} / \mathrm{g}$ ) of raw material

\section{Lipid peroxidation inhibition assay}

The method described by Jaishree et al. ${ }^{19}$ was used to evaluate the anti-lipid peroxidation capacity of the different samples. Briefly, $100 \mu \mathrm{L}$ of each extract (from 100 to $25 \mu \mathrm{g} / \mathrm{mL}$ in methanol) were added to $100 \mu \mathrm{L}$ of lecithin $(10 \mathrm{mg} / \mathrm{mL}$ in phosphate buffer $10 \mathrm{mmol}, \mathrm{pH}$ 7.4), $\mathrm{FeCl}_{3}(100 \mu \mathrm{L} ; 40 \mathrm{mmol})$ and ascorbic acid $(100 \mu \mathrm{L} ; 20 \mathrm{mmol})$ for 1 hour incubation at $37^{\circ} \mathrm{C}$. $\mathrm{HCl}(1 \mathrm{~mL}, 0.25 \mathrm{~N})$ supplemented with $15 \%$ TCA and $0.375 \%$ TBA was added to the mixture, incubated for $15 \mathrm{~min}$ at $100{ }^{\circ} \mathrm{C}$ and centrifuged (3000 rpm for $10 \mathrm{~min}$ ). The absorbance of the supernatant was read at $532 \mathrm{~nm}$ against a blank (methanol) with a microplate reader. Inhibition of lipid peroxidation was calculated as follows:

$$
\text { Lipid peroxidation inhibition } \%=\frac{A b s_{\text {Blank }}-A b s_{\text {Sample }}}{A b s_{\text {Blank }}} \times 100
$$

$A b s_{\text {Sample and }} A b s_{\text {Sample }}$ are respectively the absorbance of the blank and sample reactions. $\mathrm{IC}_{50}$ (Concentration inhibiting $50 \%$ of lipid peroxidation) was graphically determined.

\section{Total antioxidant capacity (TAOC) assay}

The TAOC evaluation was based on the formation of the phosphomolybdenum complex following the method described by Pietro et al. ${ }^{20}$ Briefly, each sample $(100 \mu \mathrm{g} / \mathrm{mL}$; final concentration) was mixed with $3 \mathrm{~mL}$ of reagent solution $\left(\mathrm{H}_{2} \mathrm{SO}_{4}, 0,6 \mathrm{M}\right.$, sodium phosphate $28 \mathrm{mM}$ and ammonium molybdate $4 \mathrm{mM}$ ). A blank consisting of $4 \mathrm{~mL}$ of each tested sample was used. The mixtures obtained are incubated at $95^{\circ} \mathrm{C}$ for $150 \mathrm{~min}$. After a cooling period to ambient temperature, $200 \mu \mathrm{L}$ of each tested mixture was taken and placed in the microplate well. TAOC are expressed in ascorbic acid equivalent (AAE) after absorbance recording against a standard curve $\left(y=0,0594 x+0,156 ; \mathrm{R}^{2}\right.$ $=0,9983)$ plotted with ascorbic acid $(0-150 \mathrm{mg} / \mathrm{L})$.

\section{Inflammatory Enzymes inhibition assay}

Xanthine oxidase inhibition: Xanthine oxidase inhibition potential was assessed according to the method developed by Ferraz Filha et al. ${ }^{21}$ with slight modifications. In brief, $20 \mu \mathrm{L}$ of enzyme solution $(0.28 \mathrm{U} / \mathrm{ml}$ in phosphate buffer $\mathrm{pH} 7.5)$ was mixed with $20 \mu \mathrm{L}$ of a 
sample (100 $\mu \mathrm{g} / \mathrm{mL}$ in DMSO), $60 \mu \mathrm{L}$ of phosphate buffer (1/15 M; $\mathrm{pH}$ 7.5 ) and then incubated at room temperature for $2 \mathrm{~min}$. The reaction was initiated by the addition of $100 \mu \mathrm{L}$ of the substrate $(150 \mu \mathrm{M}$ of xanthine in phosphate buffer) and the velocity was recorded for $3 \mathrm{~min}$ at $295 \mathrm{~nm}$ with a microplate reader. DMSO was used as negative control while quercetin was used as a reference inhibitor (positive control). Percentage of xanthine inhibition was calculated according to the equation:

$$
\% \text { of inhibition }=\frac{V o_{\text {control }}-V o_{\text {sample }}}{V o_{\text {control }}} \times 100
$$

$V o_{\text {control }}:$ Enzymatic activity without inhibitor, $V o_{\text {sample }}$ : Enzymatic activity in presence tested sample or quercetin.

\section{5-Lipoxygenase inhibition assay}

The method described by Malterud \& Rydland ${ }^{22}$ was used to assess the inhibition of lipoxygenase, with slight modifications. Briefly, $100 \mu \mathrm{L}$ of enzyme solution $(200 \mathrm{U} / \mathrm{mL})$ prepared in a boric acid buffer $(0.2 \mathrm{M} ; \mathrm{pH} 9.0)$ was mixed with $25 \mu \mathrm{L}$ of extract $(1 \mathrm{mg} / \mathrm{mL}$ in DMSO) and then incubated at room temperature for $3 \mathrm{~min}$. The reaction was then initiated by the addition of $125 \mu \mathrm{L}$ of the substrate $(250 \mu \mathrm{M}$ of linoleic acid) and the velocity was recorded for $3 \mathrm{~min}$ at $234 \mathrm{~nm}$ with a microplate reader. DMSO was used as control while quercetin and ibuprofen were used as reference compounds. Percentage of lipoxygenase inhibition was calculated according to

$$
\text { the equation: } \frac{V o_{\text {control }}-V o_{\text {sample }}}{V o_{\text {control }}} \times 100
$$

$V o_{\text {control }}$ :Enzymatic activity without inhibitor, $V o_{\text {sample }}$ : Enzymatic activity in the presence of the tested sample.

\section{Cyclooxygenases (COX-I and COX-2) inhibition assay}

The inhibition of COXs was performed using a commercially available colorimetric COX (ovine) inhibitor screening assay kit (Cayman Chemical Company, New York, NY, USA). All the inhibitors were dissolved in an appropriate solvent. The COX activity was evaluated using $\mathrm{N}, \mathrm{N}, \mathrm{N}$ ', N'-tetramethyl-phenylenediamine (TMPD) as a co-substrate, with arachidonic acid. The TMPD oxidation was monitored spectrophotometrically at $590 \mathrm{~nm}$. The inhibition percentage that was induced by $100 \mu \mathrm{g} / \mathrm{ml}$ of the sample was calculated.

\section{Statistical analysis}

The results are expressed as mean $\pm \mathrm{SD}$ for triplicate analysis. Data were subjected to one- way analysis of variance (ANOVA), where the differences between results were determined using Tukey's significant

\begin{tabular}{|c|c|c|c|c|c|}
\hline $\begin{array}{l}\text { Species/ } \\
\text { References }\end{array}$ & Extracts & $\begin{array}{l}\text { DPPH } \\
I_{50}(\mu \mathrm{g} / \mathrm{mL})\end{array}$ & $\begin{array}{l}\text { LPI } \\
I_{50}(\mu \mathrm{g} / \mathrm{mL})\end{array}$ & $\begin{array}{l}\text { FRAP } \\
(\mathrm{mmol} A \mathrm{AE} / \mathrm{g})\end{array}$ & $\begin{array}{l}\text { TAOC } \\
\text { (mg AAE/g) }\end{array}$ \\
\hline W. amplissima & $\begin{array}{l}\text { Ethanolic } \\
\text { Hydroacetonic } \\
\text { Aqueous }\end{array}$ & $\begin{array}{l}8 I . I I \pm 5.0 I \\
57.33 \pm 2.3 \\
37.25 \pm 2.5 I\end{array}$ & $\begin{array}{l}16.06 \pm 3.2 \\
11.9 \pm 0.1 \\
15.39 \pm 0.1\end{array}$ & $\begin{array}{l}1.33 \pm 0.44 \\
\mathrm{I} .20 \pm 0.52 \\
\mathrm{I} .32 \pm 0.52\end{array}$ & $\begin{array}{l}52.09 \pm 1.22 \\
53.27 \pm 2.32 \\
33.27 \pm 2.32\end{array}$ \\
\hline A. grandifolium & $\begin{array}{l}\text { Ethanolic } \\
\text { Hydroacetonic } \\
\text { Aqueous }\end{array}$ & $\begin{array}{l}72.07 \pm 4.1 \\
41.15 \pm 2.76 \\
45.04 \pm 3.03\end{array}$ & $\begin{array}{l}31.9 \pm 1.17 \\
21.06 \pm 1.31 \\
26.03 \pm 2.9\end{array}$ & $\begin{array}{l}|.09 \pm 0.1| \\
0.970 \pm 0.52 \\
0.737 \pm 0.07\end{array}$ & $\begin{array}{l}29.56 \pm 3.22 \\
44.92 \pm 3.13 \\
17.27 \pm 2.32\end{array}$ \\
\hline Quercetin & - & $9.35 \pm 1.45$ & $2.25 \pm 0.03$ & $1.43 \pm 0.14$ & nd \\
\hline Ascorbic acid & - & $25.82 \pm 1.05$ & $7.01 \pm 0.31$ & $\mathrm{Nd}$ & nd \\
\hline
\end{tabular}

Table I Comparative antioxidant activities of different extracts from W. amplissima and A. grandifolium using different methods

nd: not determined test and $\mathrm{P}<0.05$ was considered significant. Statistical analysis was performed using XLSTAT version 7.5.2. (Addinsoft FRANCE) and graphs were plotted using Origin 8.0.

\section{Results and discussions}

\section{Antioxidant activities}

Plants in adaptation to their environmental conditions produce a wide range of phytochemical compounds, which may be beneficial to humans. ${ }^{23}$ Phytoconstituents are responsible for one or more herbal preparation properties..$^{24}$ Studied plants extract antioxidant potential are presented in Table 1 . The $\mathrm{IC}_{50}$ of an extract is inversely proportional to its ability to produce activity. In the present study, the $\mathrm{IC}_{50}$ obtained varied from $37.25 \pm 2.51$ to $81.11 \pm 5.01$ for DPPH assay and from $11.9 \pm 0.1$ to $31.9 \pm 1.17$ for LPI. The best antioxidant activity using DPPH radical savaging method was obtained with aqueous extracts. With the LPI method, hydroacetonic extracts were found to be more effective. A comparison of the extract of each species by type of solvent revealed that extracts from $W$. amplissima possessed the best activities. In this study, quercetin and ascorbic acid were more effective in preventing the production of DPPH radicals. Indeed, quercetin was 3.95 times more antiradical than the aqueous extract of $W$. amplissima; the same observation was found in ascorbic acid, which was 1.44 times more effective on DPPH free radical formation than the best extract. Similarly, in the study of the lipid peroxidation prevention, the most effective extract was less preventive than quercetin and ascorbic acid. The results obtain with FRAP and TOAC assays for the different extracts of $W$. amplissima and A. grandifolium follow the same way as that get in the case of DPPH and LPI, with $W$. amplissima extracts being more effective in reducing the ferric ion and the molybdenum VI. W. amplissima extracts showed similar reduction power to that of quercetin. These results highlight the antioxidant potential of these plants and justify the usefulness of these plants in the folk medicine.

\section{Anti-inflammatory activities}

Several inflammatory diseases treatment is based on the inhibition of enzymes involved in the production of mediators initiating and/or amplifying the inflammatory process. ${ }^{25}$ Herbal based remedies with anti-inflammatory activities constitute the foundation of promising curative therapy. ${ }^{26,27}$ Table 2 presents results obtained on the inhibition potential of $W$. amplissima and A. grandifolium on XO, LOX-15 and COX-1 and COX-2. The anti-inflammatory potential was estimated by the determination of the concentration of each extract that inhibits $50 \%$ of the enzyme activity. Hydroacetonic extracts of both plants were more effective in inhibiting the different enzymes compared with ethanolic and aqueous extracts. 
Table 2 W. amplissima and A. grandifolium inhibiting potential on xanthine oxidase, lipoxygenase and cyclooxygenases comparison

\begin{tabular}{|c|c|c|c|c|c|}
\hline $\begin{array}{l}\text { Species/ } \\
\text { References }\end{array}$ & Extracts & $\begin{array}{l}\text { XO } \\
I C_{50}(\mu g / m L)\end{array}$ & $\begin{array}{l}\text { LOX } \\
I^{I C_{50}}(\mu g / m L)\end{array}$ & $\begin{array}{l}\text { COX I } \\
I_{50}(\mu \mathrm{g} / \mathrm{mL})\end{array}$ & $\begin{array}{l}\text { COX } 2 \\
I_{50}(\mu \mathrm{g} / \mathrm{mL})\end{array}$ \\
\hline \multirow[t]{2}{*}{ W. amplissima } & Ethanolic & $34.16 \pm 2.22$ & $33.18 \pm 2.43$ & $73.06 \pm 2.34$ & $78.5 \mathrm{I} \pm 2.45$ \\
\hline & Aqueous & $29.70 \pm 2.18$ & $34 .|5 \pm| .5 \mid$ & $53.33 \pm 1.92$ & $33.31 \pm 2.52$ \\
\hline A. grandifolium & Ethanolic & $51.67 \pm 2.07$ & $66.95 \pm 4.13$ & $62.14 \pm 2.91$ & $51.01 \pm 1.73$ \\
\hline Quercetin & - & $5.24 \pm 0.82$ & $10.62 \pm 2.01$ & $15.89 \pm 2.27$ & $9.23 \pm 0.42$ \\
\hline Ibuprofen & - & nd & $22.13 \pm 4.12$ & $|8.63 \pm 0.6|$ & $93.33 \pm 4.39$ \\
\hline
\end{tabular}

nd: not determined

$\mathrm{XO}$ inhibition was statistically the same for the ethanolic extract of $W$. amplissima and aqueous extract of $A$. grandifolium. Hydroacetonic extract of $W$. amplissima presented the highest potential to inhibit XO with $25.91 \pm 1.98 \mu \mathrm{g} / \mathrm{mL}$ as $\mathrm{IC}_{50}$, while ethanolic extract of $A$. grandifolium was the weakest to inhibit this enzyme.

LOX-15 inhibition was statistically the same for ethanolic and aqueous extracts of $W$. amplissima. The strongest inhibition was obtained with the hydroacetonic extract of $W$. amplissima. Moreover, compared to $A$. grandifolium, it presented the best activity on this enzyme whatever the type of solvent used for the extraction.

COX-1 and COX-2 were differently inhibited by the species studied. For both species, the hydroacetonic extracts were the most effective to inhibit these enzymes. A. grandifolium was more effective on COX-1 with $42.06 \pm 1.17$, while $W$. amplissima was found to be more effective on COX-2 isoform with $30.51 \pm 2.45 \mu \mathrm{g} / \mathrm{mL}$ as $\mathrm{IC}_{50}$.
The inhibitory activities of the extracts on the different enzymes compared with that of the references used showed that quercetin was more effective than the tested extracts. In the case of ibuprofen, for LOX and COXs inhibitions, the comparison showed that extract was less effective to inhibit LOX and COX-1 isoform, whereas in the COX-2 inhibition extracts are more active than ibuprofen. These results strongly support the use of these plants in folk medicine to threat some inflammation condition.

\section{Phytochemical contents}

The results obtained on the total phenolic and total flavonoid contents are shown in Figures $1 \& 2$. All the extracts contain phenolic compounds (including flavonoids), and the content in these compounds varied according to each solvent used for extraction.

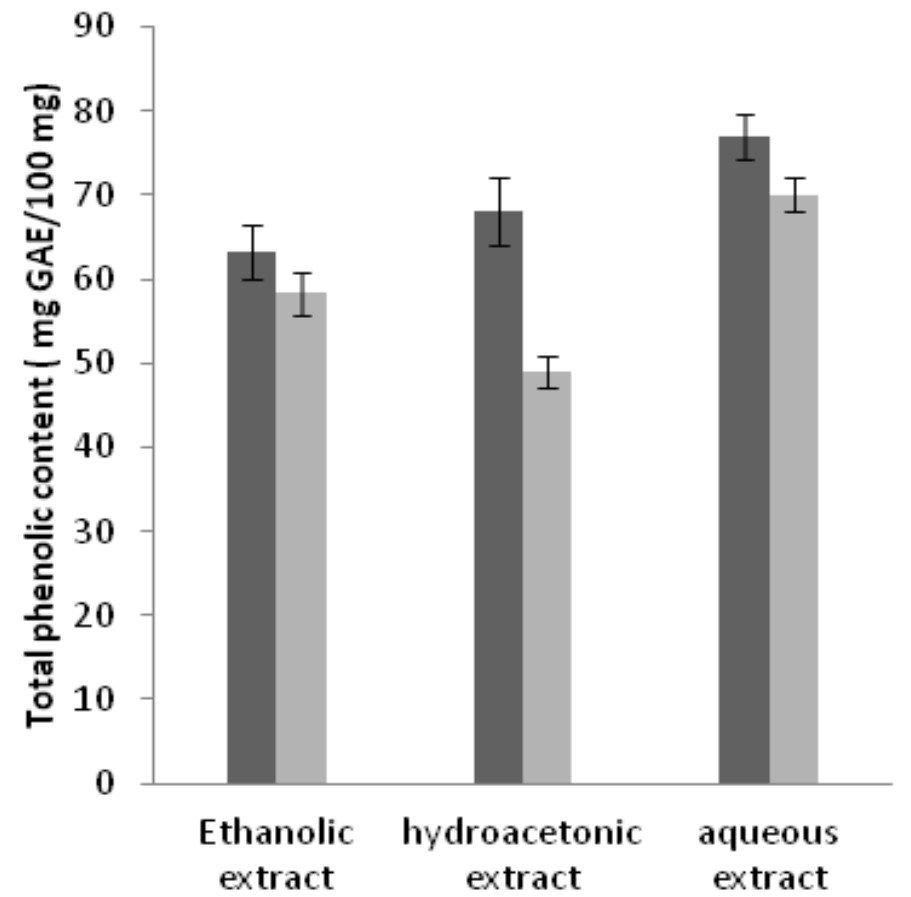

W.amplissima

A. grandifolium

extract extract extract

Figure I Comparison of total phenolic contents in W. amplissima and A. grandifolium. 


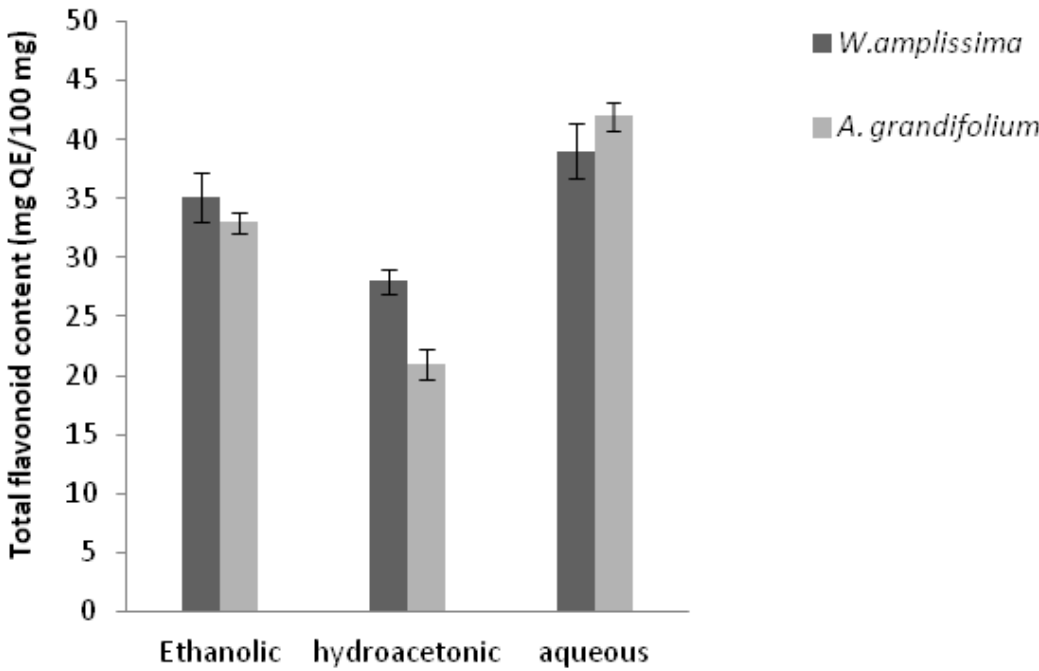

Figure 2 Comparison of total flavonoid contents in W. amplissima and A. grandifolium.

The content of total polyphenols varied from $63.07 \pm 3.01 \mathrm{mg} \mathrm{GAE} /$ $100 \mathrm{mg}$ of extract (ethanolic extract) to $77.04 \pm 3.26 \mathrm{mg} \mathrm{GAE} / 100 \mathrm{mg}$ of extract (aqueous extract) for $W$. amplissima, while for A. grandifolium these values were respectively of $57,49 \pm 2.52 \mathrm{mg}$ GAE/ $100 \mathrm{mg}$ of extract and $70.69 \pm 1.69 \mathrm{mg}$ GAE/ $100 \mathrm{mg}$ of extract in ethanolic extract and in aqueous extract. Hydro-acetone $(80 / 20 \mathrm{v} / \mathrm{v})$ yielded 1.45 fold more phenolic in W.amplissima than in A. grandifolium. Under the experimental conditions, significant differences were observed for each compared solvent. Phenolic compounds are metabolites widely distributed in plants. However, their amount varies to each material source ${ }^{28}$. In this study, the major amount of phenolic compounds in both species is hydrophilic kind.

Flavonoids are found in each extract (Figure 2). Comparison in the studied plants revealed that the amount yielded varies according to the extraction solvent. Extraction made with ethanol and acetone, yielded more flavonoids from $W$. amplissima than A. grandifolium, whereas when water was the extraction solvent, the amount extracted from A. grandifolium was greater than that of $W$. amplissima. Flavonoids constitute one of the largest group of plant phenolic compounds. ${ }^{29}$ They are present in all the obtained extract. The highest amount of flavonoids is, as in the case of total phenolics, obtained with water as extracting solvent.

Antioxidant capacities of herbal formulation depend on different parameters such as the phytoconstituents present ${ }^{30}$ and the mechanism by which the antioxidant activities are achieved. ${ }^{31}$ Differences in antioxidant activities for $W$. amplissima and A. grandifolium using different experimental methods may be explained by the fact that depending on plant matrix and the extracting solvent, particular phytomolecules are drained. These molecules are different in type and/or in amount.

\section{Conclusion}

The present study highlighted the antioxidant and antiinflammatory activities and also the polyphenolic compound content of the extracts of W.amplissima and A. grandifolium. Antioxidant and anti-inflammatory activities of both plants might explain their traditional uses like care given to persons suffering after insect's bites and those affected with skin and respiratory apparatus infections. The comparison of diverse studied activities revealed that $W$. amplissima possesses more therapeutic potential than $A$. grandifolium in terms of antiradical and reduction potentials as well as in the inhibition of enzymes involved in the inflammation process. Results obtained will constitute the basis of the next step of our research, which will focus on the isolation of main active polyphenol compounds.

\section{Acknowledgments}

Authors are grateful to APPEAR 75 and TWAS 12-044 RG/BIO/ $\mathrm{AF} / \mathrm{AC} \mathrm{G}$ for providing laboratory facilities that have made this work possible.

\section{Conflicts of interests}

Authors have no conflicts of interest to declare.

\section{References}

1. Medzhitov R. Inflammation 2010 : New adventures of an old flame. Cell. 2010;140(6):771-776.

2. Hunter P. The inflammation theory of disease. The growing realization that chronic inflammation is crucial in many diseases opens new avenues for treatment. EMBO Rep. 2012;13(11):968-970.

3. Signore A. About inflammation and infection. EJNMMI Res. 2013;3(1):1-2.

4. Chen L, Deng H, Cui H, et al. Inflammatory responses and inflammationassociated diseases in organs. Oncotarget. 2018;9(6):7204-7218.

5. Rutkowski R, Pancewicz SA, Rutkowski K RJ. Reactive oxygen and nitrogen species in inflammatory process. Pol Merkur Lek 2007;23(134):131-136.

6. Abu-Serie MM, Habashy NH, Attia WE. In vitro evaluation of the synergistic antioxidant and anti-inflammatory activities of the combined extracts from Malaysian Ganoderma lucidum and Egyptian Chlorella vulgaris. BMC Complement Altern Med. 2018;18(1):1-13.

7. Forrester SJ, Kikuchi DS, Hernandes MS, et al. Reactive oxygen species in metabolic and inflammatory signaling. Circ Res. 2018;122(6):877902 .

8. Strong MH, Strong EK. The nature of recognition memory and of the localization of recognitions. Am J Psychol. 2013;16(5):821-847. 
9. Bamisaye FA, Ajani EOMJ. Prospects of ethnobotanical uses of pawpaw (Carica Papaya). J Med Plants. 2013;1(4):171-177.

10. Kasote DM, Katyare SS, Hegde M V, et al. Significance of antioxidant potential of plants and its relevance to therapeutic applications. Int J Biol Sci. 2015;11(8):982-991.

11. Rahman AHMM, Gondha R. Taxonomy and traditional medicine practices on malvaceae ( Mallow Family) of Rajshahi, Bangladesh. Open J Bot. 2016;3(1):160-172.

12. Saleem $\mathrm{S}$, khalid U. Phytochemical and pharmacological importance of Malva neglecta : an updated review. Pharmacol. 2018;2:52-62.

13. Tanumihardja M, Natsir N, Mattulata IK, et al. Pharmacological evaluation of ethanol extract of Sida rhombifolia L. roots ( Malvaceae ). J Chem Pharm Res. 2016;8(1):770-774.

14. Singleton VL, Orthofer R, Lamuela-Raventos R.M. Analysis of total phenols and other oxidation substrates and antioxidants by means of folin-ciocalteu reagent. Methods Enzymol. 1999;299:152-178.

15. Arvouet-Grant A, Venant B, Pourrat A, et al. Standardization of propolis extract and identification of principal constituents. J Pharm Belg. 1994;49(6):468-994.

16. Velázquez E, Tournier HA, Mordujovich De Buschiazzo P, et al. Antioxidant activity of Paraguayan plant extracts. Fitoterapia. 2003;74(1-2):91-97.

17. Lamien-Meda A, Lamien C, Compaoré M, et al. Polyphenol content and antioxidant activity of fourteen wild edible fruits from Burkina Faso. Molecules. 2008;13(3):581-594.

18. Ferraz Filha ZS, Vitolo IF, Fietto LG, et al. Xanthine oxidase inhibitory activity of Lychnophora species from Brazil (“Arnica”). $J$ Ethnopharmacol. 2006;107(1):79-82.

19. Prieto P, Pineda M, Aguilar M. Spectrophotometric quantitation of antioxidant capacity through the formation of a phosphomolybdenum complex: specific application to the determination of vitamin E. Analytical Biochemistry. 1999;269(2):337-341.

20. Malterud K, Rydland M. Inhibitors of 15-lipoxigenase from orange peel. J Agric Food Chem. 2000;48:5576-5580.
21. Beg S, Swain S, Hasan H, et al. Systematic review of herbals as potential anti-inflammatory agents: recent advances, current clinical status and future perspectives. Pharmacogn Rev. 2011;5(10):120-137.

22. Altemimi A, Lakhssassi N, Baharlouei A, et al. Phytochemicals: extraction, isolation, and identification of bioactive compounds from Plant extracts. Plants (Basel). 2017;6(4). pii: E42.

23. Charles AD. Anti-inflammatory agents: present and future. Cell. 2010;140(6):935-950.

24. Ekor M. The growing use of herbal medicines: issues relating to adverse reactions and challenges in monitoring safety. Front Neurol. 2014;4 (1):1-10.

25. Caesar LK, Cech NB. Synergy and antagonism in natural product extracts: When 1+1 does not equal 2. Nat Prod Rep. 2019;36(6):869888

26. Zhou X, Seto SW, Chang D, et al. Synergistic effects of Chinese herbal medicine: a comprehensive review of methodology and current research. Front Pharmacol. 2016;7:201

27. Erkan N, Akgonen S, Ovat S, et al. Phenolic compounds profile and antioxidant activity of Dorystoechas hastata L. Boiss et Heldr. Food Res Int. 2011;44(9):3013-3020.

28. Subba A, Mandal P. Pharmacognostic studies and in vitro antioxidant potential of traditional polyherbal formulation of west Sikkim with Asparagus Spp. Pharmacogn J. 2015;7(6):348-355.

29. Smail B. Determination of the antioxidant capacity of red fruits by minuaturized spectrophotometry. J Braz Chem Soc. 2019;30(5):11081114.

30. Lee MT, Lin CT, Yu B, et al. Antioxidant capacity of phytochemicals and their potential effects on oxidase status in animals-A review. AsianAustrlas J Anim Sci. 2017;30(3):299-308.

31. Wink M. Modes of action of herbal medicines and plant secondary metabolites. Medicines. 2015;2(3):251-286. 